\title{
2 Actin acting at the Golgi
}

\section{Gustavo Egea - Carla Serra-Peinado • \\ 4 Laia Salcedo-Sicilia $\cdot$ Enric Gutiérrez-Martínez}

Accepted: 3 June 2013

6 (C) Springer-Verlag Berlin Heidelberg 2013

7 Abstract The organization, assembly and remodeling of 8 the actin cytoskeleton provide force and tracks for a variety 9 of (endo)membrane-associated events such as membrane 10 trafficking. This review illustrates in different cellular 11 models how actin and many of its numerous binding and 12 regulatory proteins (actin and co-workers) participate in the 13 structural organization of the Golgi apparatus and in traf14 ficking-associated processes such as sorting, biogenesis and 15 motion of Golgi-derived transport carriers.

Keywords Golgi apparatus - Cytoskeleton - Actin · Spectrin · Myosin $\cdot$ Rho GTPases

\section{Introduction}

The function of the Golgi apparatus is the result of a complex interaction between the molecules that establish its architecture, those that determine protein transport and those that integrate signals from either outside or inside the cell. Cytoskeletal elements (microtubules, actin filaments or microfilaments and intermediate filaments) integrate these processes. Association and coordination between them as well as their respective binding and regulatory

\footnotetext{
G. Egea $(\bowtie) \cdot$ C. Serra-Peinado · L. Salcedo-Sicilia

E. Gutiérrez-Martínez

Departament de Biologia Cel-lular, Immunologia i

Neurociències, Facultat de Medicina, Universitat de Barcelona, C/Casanova, 143, 08036 Barcelona, Spain

e-mail: gegea@ub.edu

G. Egea

Institut d'Investigació Biomèdica August Pi i Sunyer (IDIBAPS)

i de Nanociencia i Nanotecnologia $\left(I^{2}{ }^{2}\right.$ B $)$, Universitat de

Barcelona, 08036 Barcelona, Spain
}

proteins are present in the majority of endomembrane systems, including the Golgi apparatus. While its basic function is highly conserved, the Golgi varies greatly in shape and number from one organism to another. Briefly, it ranges from dispersed cisternae or isolated tubular networks as occurs in algae, protozoa and the yeast Saccharomyces cerevisiae, to a pile of flattened cisternae aligned in parallel and known as the Golgi stack. This, depending on the organism examined, could be present in a single (fungi and the yeast Pichia pastoris) or multiple copies, the latter being scattered throughout the cytoplasm (plants and Drosophila) or organized as a ribbon around centrioles (vertebrates) (daSilva et al. 2004; Hawes and Satiat-Jeunemaitre 2005; He et al. 2004; He 2007; Henderson et al. 2007; Kondylis and Rabouille 2003; Ladinsky et al. 1999; Lowe 2011; Mogelsvang et al. 2003; Pelletier et al. 2002; Preuss et al. 1992; Rambourg and Clermont 1986; Rambourg et al. 2001; Ramírez and Lowe 2009; Rios and Bornens 2003; Rossanese et al. 1999). The cytoskeleton determines the location of the Golgi, and depending on the cellular model, either microtubules or actin filaments have the greater influence (Egea and Rios 2008), the impact of intermediate filaments being very limited (Gao and Sztul 2001; Gao et al. 2002; Styers et al. 2006; Toivola et al. 2005). Historically, microtubules were the first cytoskeleton element to be linked to the Golgi structure and function (Thyberg and Moskalewski 1999), and only later was it firmly established that actin and associated proteins (actin et al.) also played a significant role (for recent reviews see Brownhill et al. 2009; Egea et al. 2006; Harris and Tepass 2010; Hehnly and Stamnes 2007; Lanzetti 2007; Loubéry and Coudrier 2008; Myers and Casanova 2008; Ridley 2006; Smythe and Ayscough 2006; Soldati and Schliwa 2006). Here, we provide an up-to-date overview of the structural and transport consequences of the coupling

\begin{tabular}{|c|c|c|c|c|}
\hline & Journal : Large 418 & Dispatch & 24-6-2013 & Pages: 14 \\
\hline & $\begin{array}{l}\text { Article No. : } 1115 \\
\text { MS Code : HCB-2664-13-Roth }\end{array}$ & $\begin{array}{l}\square \text { LE } \\
\boldsymbol{C P}_{\mathrm{CP}}\end{array}$ & & $\begin{array}{l}\square \text { TYPESET } \\
\boldsymbol{~ D I S K ~}\end{array}$ \\
\hline
\end{tabular}


between the actin-based cytoskeleton and the Golgi in a variety of cellular models that are commonly used to investigate membrane trafficking events.

\section{Actin and co-workers in the structural organization of the Golgi apparatus}

The first experimental evidence that actin and the Golgi interacted was that Golgi membranes and Golgi-derived vesicles contained actin and actin-binding proteins (Heimann et al. 1999) and that the Golgi invariably compacted when cells were treated with a variety of naturally occurring substances that perturbed the actin organization and its dynamics, which mainly include cytochalasins, latrunculins, jasplakinolide and botulinum toxins and are known generically as actin toxins or actin drugs (Fig. 1) (di Campli et al. 1999; Valderrama et al. 1998, 2000, 2001). At ultrastructural level, the compacted Golgi was seen to depend on whether actin drugs depolymerized or stabilized actin filaments, giving rise, respectively, to dilatation (Fig. 1) or fragmentation/perforation of cisternae. Moreover, these ultrastructural impairments occurred in a microtubule-independent manner, which ruled out synergic cooperation between microtubules and actin filaments controlling the shape and integrity of Golgi cisternae (Lazaro-Dieguez et al. 2006). Golgi compactness is consistently seen when actin partners present at the Golgi are perturbed, such as after the depletion of the Arp2/3 activator WASp homologue associated with actin, Golgi membranes and microtubules (WHAMM)
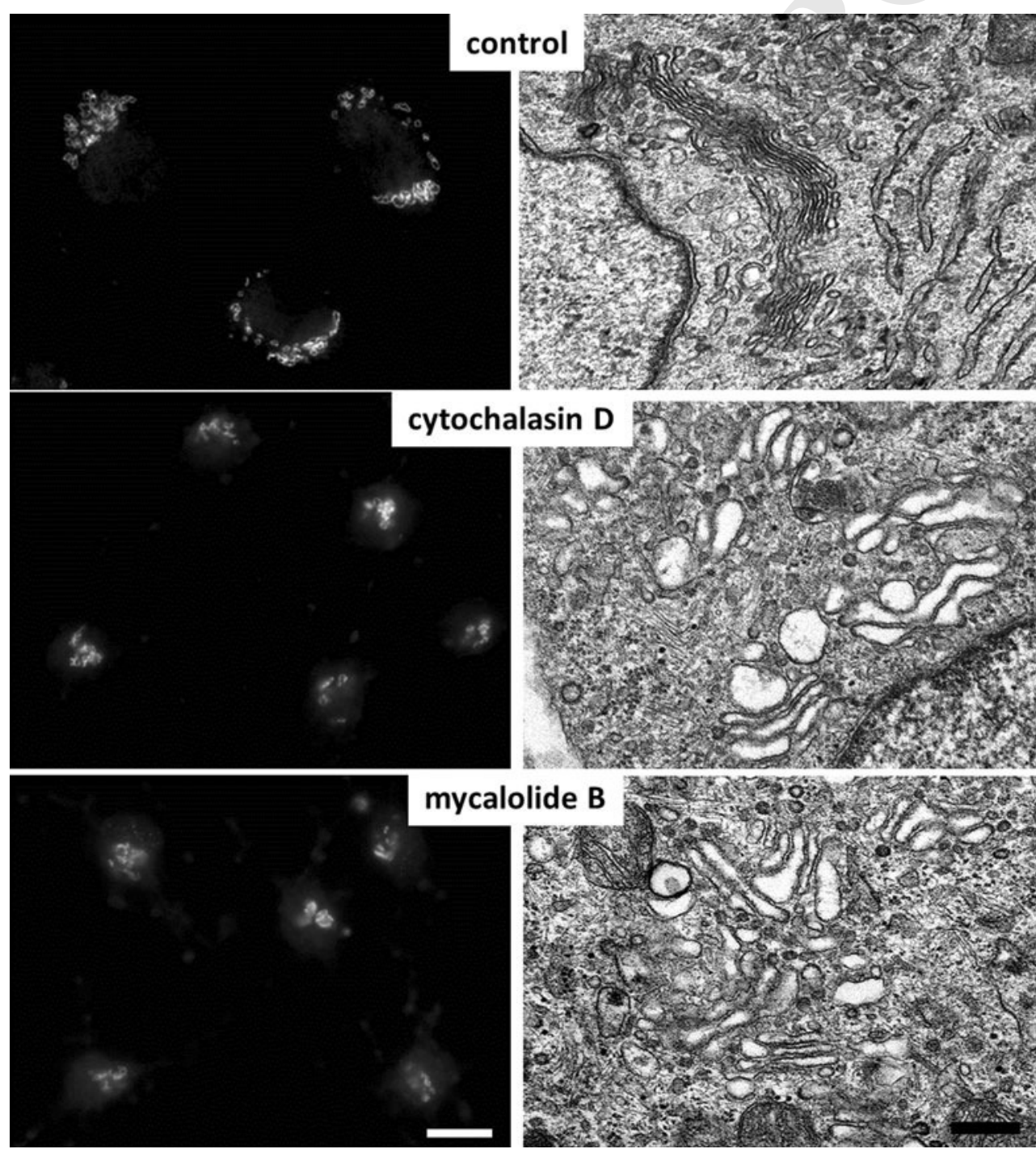

Fig. 1 Alterations in the Golgi morphology after actin cytoskeleton disruption. NRK cells treated with the filamentous-actin-depolymerizing agents cytochalasin D or mycalolide B show a compacted Golgi (stained to GM130) in contraposition with the extended one shown by

untreated cells. At ultrastructural level, both actin toxins cause dilatation of cisternae and an abnormally high number of peri-Golgi vesicles. Bar for epifluorescence images, $10 \mu \mathrm{m}$; bar for ultrastructural images, $200 \mathrm{~nm}$

\begin{tabular}{|c|c|c|c|c|}
\hline & Journal : Large 418 & Dispatch & 24-6-2013 & Pages : \\
\hline & $\begin{array}{l}\text { Article No. : } 1115 \\
\text { MS Code : } \quad \text { HCB-2664-13-Roth }\end{array}$ & $\begin{array}{l}\square \mathrm{LE} \\
\boldsymbol{\sim}_{\mathrm{CP}} \\
\end{array}$ & & $\begin{array}{l}\square \text { TYPESET } \\
\boldsymbol{v} \text { DISK } \\
\end{array}$ \\
\hline
\end{tabular}


(Campellone et al. 2008), cortactin (Kirkbride et al. 2012) or myosin 18A, an unconventional myosin that connects filamentous actin to the phosphatidylinositol 4-phosphate (PI4P)-binding protein GOLPH3 (Dippold et al. 2009; Ng et al. 2013) (Fig. 2a). However, in some cases, interference with the actin machinery produces fragmentation (and dispersion) of the Golgi, which occurs after the depletion or constitutive activation of actin nucleators formin family members mDia (mammalian Diaphanus), the formin-like 1/FMNL1 and INF2 (Colon-Franco et al. 2011; Ramabhadran et al. 2011; Zilberman et al. 2011). Taken together, these findings reinforce the notion that the proper regulation of actin at the Golgi is necessary to maintain the structural integrity of the Golgi apparatus.

Other important cytoskeletal organization in which actin is integrated corresponds to that formed by spectrin. In red blood cells, the spectrin-based cytoskeleton determines their characteristic biconcave shape and localizes as a bidimensional network beneath the plasma membrane. Defects in major components (spectrin, ankyrin and protein 4.1) are associated with abnormal cell shape and membrane fragility (Lux 1979). By analogy with erythrocytes, the Golgi-associated spectrin skeleton could act as an extended, two-dimensional interactive platform on the cytoplasmic surface of cisternae, regulating its shape and transport functions (Beck et al. 1994; Beck and Nelson 1998; Holleran and Holzbaur 1998; Godi et al. 1998; De Matteis and Morrow 2000). While mammalian red blood cells contain only one type of spectrin tetramer $(\alpha \mathrm{I} \beta \mathrm{I}$ subunits), nucleated cells contain numerous isoforms of both subunits, being BIII spectrin present at the Golgi
(Salcedo-Sicilia et al. 2013; Stankewich et al. 1998). Other isoforms of the spectrin-based cytoskeleton components typically present in the plasma membrane of red blood cells have also been localized in the Golgi, such as $\beta$ and $\gamma$ actin (Valderrama et al. 2000), ankyrins Ank $_{\mathrm{G} 119}$ and $\mathrm{Ank}_{195}$ (Beck et al. 1997; Devarajan et al. 1996, 1997), protein 4.1B (Kang et al. 2009), anion exchanger AE2 (Holappa et al. 2001, 2004) and tropomyosin (Percival et al. 2004). $\beta$ III spectrin is required to maintain the characteristic Golgi architecture since its functional interference or knockdown causes fragmentation and dilation of Golgi membranes (Salcedo-Sicilia et al. 2013; Siddhanta et al. 2003). Most likely, the Golgi fragmentation is produced by the loss of the direct interaction of $\beta$ III spectrin with the dynein/ dynactin motor complex subunit Arp1 (Holleran et al. 2001), and distal cisternae swelling is caused by alterations in the activity of ionic channels, or in the mechanical stability of cisternae or both. Strikingly, actin toxins did not perturb the localization of $\beta$ III spectrin at the Golgi, which indicates that actin dynamics does not participate in the association of $\beta$ III spectrin with Golgi membranes, but PI4P was crucial in such interaction (Salcedo-Sicilia et al. 2013). The ultrastructural alterations caused by actin drugs (Lazaro-Dieguez et al. 2006) and the depletion of BIII spectrin (Salcedo-Sicilia et al. 2013) indicate that they provide the necessary mechanical stability to cisternae to prevent their expected spontaneous swelling due to the hyperosmotic protein content in transit through the Golgi stack. Ion regulatory molecules such as vacuolar $\mathrm{H}^{+}$ATPase (Moriyama and Nelson 1989) and cation (NHEs) exchangers (Nakamura et al. 2005) either resident in the
A

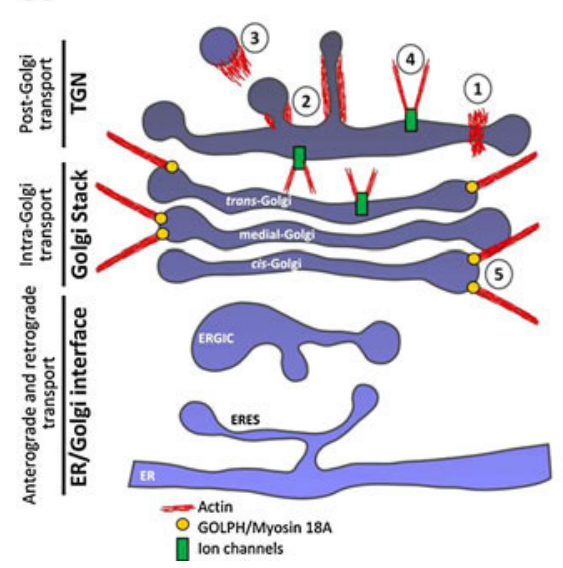

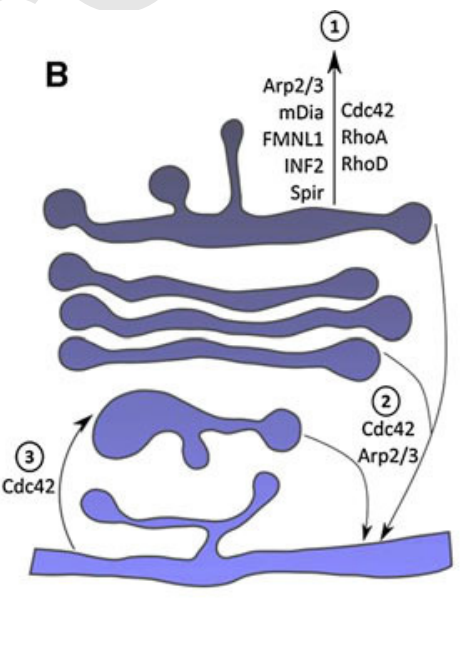

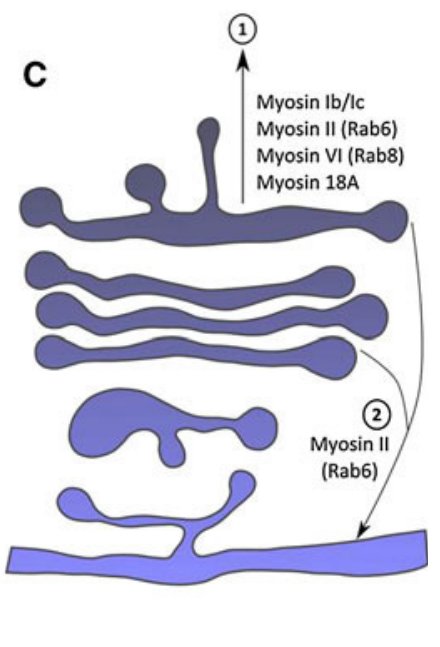

Fig. 2 Diagram of the secretory membrane trafficking pathways and events in which actin, Rho GTPases, actin nucleators and myosin motors are known to participate. a Actin filaments, their polymerization and dynamics could act as a force for the scission (1), pulling (2) and propelling (3) of the transport carrier generated in cisternae, and for maintaining the flattened shape of cisternae (4) and the extended Golgi ribbon (5). b Rho GTPases and actin nucleators reported to act in the post-Golgi (1), Golgi-to-ER (2) and ER-to-Golgi (3) protein transport. c Myosin motors and their known Rab protein effectors in the post-Golgi (1) and Golgi-to-ER (2) protein transport. See the text for details

$\begin{array}{lll}\text { Journal : Large } 418 & \text { Dispatch : 24-6-2013 } & \text { Pages : 14 } \\ \text { Article No. : } 1115 & \square \text { LE } & \square \text { TYPESET } \\ \text { MS Code : HCB-2664-13-Roth } & \sim_{\text {CP }} & \checkmark \text { DISK }\end{array}$


Golgi or in transit to the plasma membrane could contribute to this actin/spectrin-dependent cisternal mechanical stability, finely regulating intra-Golgi ion concentration and $\mathrm{pH}$ homeostasis. In accordance with this idea are the reports that the sorting of some secretory cargo at the transGolgi network (TGN) by the actin-filament-severing protein ADF/cofilin activates the calcium ATPase 1 (SPCA1) (Curwin et al. 2012; von Blume et al. 2009, 2011) and that the actin depolymerisation-induced cisternae swelling is accompanied by a rise in the intra-Golgi $\mathrm{pH}$ (Lazaro-Dieguez et al. 2006). Therefore, actin seems to regulate the activity of some ionic regulatory proteins present in Golgi membranes, similarly to what occurs at the plasma membrane (Mazzochi et al. 2006) (Fig. 2a).

\section{Actin and co-workers in the sorting, biogenesis and motion of transport carriers at the Golgi}

Filamentous actin

A key aspect in the structure of polarized cells is the maintenance of polarized molecular organization. This is based on highly specific sorting machinery at the exit of the TGN (Rodriguez-Boulan et al. 2005). Cytoskeleton elements form part of this machinery, and the integrity of actin filaments is necessary for efficient delivery of some proteins destined for the apical or the basolateral plasma membrane domains in both polarized and non-polarized cells, but not for the transport of lipid raft-associated proteins (Jacob et al. 2003; Lazaro-Dieguez et al. 2007; Lebreton et al. 2008) (Fig. 2a).

\section{Rho GTPases and actin nucleators}

Tight control of the coupling between Golgi-associated actin polymerization and membrane elongation and fission reactions prevents the structural and functional collapse of the Golgi. Part of this control can be achieved by regulating the activation state of Rho GTPases and downstream effectors in Golgi membranes (Fig. 2b). Briefly, classical Rho GTPases cycle between active GTP-bound and inactive GDP-bound forms. There are three types of proteins that regulate this cycle: guanine nucleotide exchange factors (GEFs) activate GTPases; GTPase-activating proteins (GAPs) inactivate them and guanine nucleotide dissociation inhibitors (GDIs) keep GTPases in a GDP-inactive form. Cdc42, which was the first RhoGTPase to be localized in the Golgi (Erickson et al. 1996; Fucini et al. 2000; Luna et al. 2002; Matas et al. 2004; Prigozhina and Waterman-Storer 2004; Wu et al. 2000), affects ER/Golgi interface and post-Golgi intracellular trafficking (Harris and Tepass 2010) (Fig. 2b). Constitutively active and inactive Cdc42 mutants block the ER-to-Golgi transport of anterograde cargo (VSV-G) (Wu et al. 2000). The overexpression and activation of Cdc42 (Luna et al. 2002) or the knockdown of Cdc42 GAP ARHGAP21 (also known as ARHGAP10) (Hehnly et al. 2009) inhibit the Golgi-to-ER transport of retrograde cargo (Shiga toxin) (Fig. 2b). Cdc42 binds $\gamma$ COPI subunit recruiting N-WASP and Arp2/3 to Golgi membranes. p23 (a receptor for cargo containing the dilysine motif in the $\mathrm{COOH}$-terminal) competes with Cdc42 for binding to $\gamma$ COPI subunit. Cargo loading by p23 disrupts the Ccdc $42-\gamma \mathrm{COP}$ interaction and recruits dynein to promote the dynein-dependent ER-to-Golgi transport (Chen et al. 2005) (Fig. 2b). Therefore, Cdc42 coordinates actin- and microtubule-dependent motility of transport carriers at the ER/Golgi interface (Hehnly and Stamnes 2007) (Fig. 2b). In post-Golgi trafficking (Fig. 2b), the expression of constitutively active or inactive $\mathrm{Cdc} 42$ mutants slows the exit of basolateral protein markers and accelerates the exit of apically destined ones (Cohen et al. 2001; Kroschewski et al. 1999; Musch et al. 2001). ARHGAP21/10 and Cdc42 GEFs Fgd1 and Dbs are also present in Golgi membranes regulating post-Golgi vesicular transport (Dubois et al. 2005; Egorov et al. 2009; Estrada et al. 2001; Kostenko et al. 2005; Menetrey et al. 2007).

At first, Cdc42 was believed to be the only Rho GTPase working at the Golgi (Matas et al. 2005), but recent data also implicate other Rho GTPases and downstream effectors (Fig. 2b). This is the case for RhoA with mDia (Ziberman et al. Zilberman et al. 2011) and Citron-N (Camera et al. 2003), RhoD with WHAMM (Gad et al. 2012) and Rac1 and its exchange factor $\beta$-PIX with the clathrin heavy-chain-binding protein CYFIP/Sra/PIR121 (Anitei et al. 2010). RhoD-WHAMM and the ARF1primed Rac1-CYFIP/Sra/PIR121 protein complexes stimulate the Arp2/3-induced actin polymerization at the Golgi and vesicle biogenesis (Anitei et al. 2010; Campellone et al. 2008). The ROCK/LIM kinase (LIMK) signaling pathway and its substrate cofilin are necessary for apical cargoes (Rosso et al. 2004; Salvarezza et al. 2009). RhoA GEF-H1 interacts with exocyst component Sec5, which in turn activates RhoA-regulating post-Golgi trafficking and assembly of other exocyst components (Pathak et al. 2012).

The presence in Golgi membranes of molecular components that trigger actin polymerization with those that control vesicular budding and fission suggests intimate molecular coupling between them, which is strongly similar to that observed during endocytosis (Mooren et al. 2012). Actin assembly provides the structural support that facilitates the formation of transport carriers in the lateral portions of Golgi membranes (Fig. 2a). This can be achieved by generating force through actin polymerization triggered by actin nucleators, which in turn can be

\begin{tabular}{|l|lll|}
\hline Journal : Large 418 & Dispatch : 24-6-2013 & Pages : 14 \\
Article No. : 1115 & $\square$ & $\square$ TYPESET \\
MS Code : HCB-2664-13-Roth & $\sim_{\text {CP }}$ & $\checkmark$ DISK \\
\hline
\end{tabular}


accompanied by the mechanical activity of actin motors (myosins). In accordance with this idea, Arp2/3, mDia, formin-like 1/FMNL1 and INF2 and Spir1 are all present in the Golgi (Carreno et al. 2004; Chen et al. 2004; ColonFranco et al. 2011; Kerkhoff et al. 2001; Matas et al. 2004; Ramabhadran et al. 2011; Zilberman et al. 2011) (Fig. 2b). At the TGN, there is a functional coupling between dynamin-mediated membrane fission and Arp2/3mediated actin-based mechanisms (Cao et al. 2005; Carreno et al. 2004; Kerkhoff et al. 2001; Kessels and Qualmann 2004; Praefcke and McMahon 2004). Interference with dynamin2/cortactin or dynamin2/syndapin2/ cortactin blocks post-Golgi protein transport (Cao et al. 2005; Kessels et al. 2006; Salvarezza et al. 2009). As indicated above, in early Golgi compartments, there is a functional connection between actin polymerization governed by $\mathrm{Cdc} 42$, coatomer (COPI)-mediated transport carrier formation and microtubule motor-mediated motion. WASH (Wiskott-Aldrich syndrome protein and SCAR homolog) is another Arp2/3 activator that regulates the cation-independent mannose phosphate receptor (CI-MPR) trafficking from endosomes to the Golgi, forming an endosomal subdomain containing Arp2/3, F-actin, tubulin and retromer components (Gomez and Billadeau 2009). The local fine regulation of actin dynamics on the transport carrier assembly could represent an early step that precedes its scission in the lateral portions of cisternae for subsequent switching to microtubule tracks for motion (Fig. 2a).

Actin nucleation/polymerization activity associated with Arp2/3 on Golgi membranes could also give rise to the formation of actin comet tails, which consist of filamentous actin and various actin-binding proteins that focally assemble and grow on a membrane surface (Campellone and Welch 2010) (Fig. 2a). After the overexpression of phosphatidylinositol 5-kinase, actin tails have been observed only in raft-enriched TGN-derived vesicles (Guerriero et al. 2006; Rozelle et al. 2000). An in vitro approach in liposomes showed actin polymerization occurring after the recruitment of the activated form of ARF1 around liposomes. This actin polymerization was dependent on Cdc42 and N-WASP present in HeLa cell extracts and resulted in the formation of actin comets, which pushed the ARF1-containing liposome forward (Heuvingh et al. 2007). However, actin comet tails do not seem to be an efficient mechanism to provide directionality for transport carriers, in which microtubule tracks, and to lesser extent actin ones, seem more suitable. However, an actin comet tail-like mechanism could easily provide brief local force to facilitate the final separation of the transport carrier at the lateral rims of Golgi cisternae (Fig. 2a) similarly to what happens during endocytosis (Merrifield 2004; Merrifield et al. 2005; Taylor et al. 2012), and/or for its translocation to closely arranged microtubule tracks (Egea et al. 2006) (see green arrows in Fig. 3).

Myosin motors

In addition to actin polymerization, myosins also generate a force, which can selectively couple protein sorting and transport carrier biogenesis and motility. Class I myosin is a monomeric, non-processive motor that binds to Golgi membranes and is present on apical Golgi-derived vesicles of polarized cells (Almeida et al. 2011; Fath and Burgess 1993; Jacob et al. 2003; Montes de Oca et al. 1997; Tyska et al. 2005). Myosin Ib together with actin polymerization have recently been shown to participate in membrane remodeling to form tubular transport carriers at the TGN directed to endosomes and the plasma membrane (Almeida et al. 2011; Coudrier and Almeida 2011) (Fig. 2c). It has been hypothesized that myosin Ib spatially controls actin assembly at the TGN, interacting with F-actin via its motor domain and at the membrane via its $\mathrm{PH}$ domain. Such interaction generates a force concomitantly with the polymerization of actin, leading to membrane curvature changes (Coudrier and Almeida 2011; Loubéry and Coudrier 2008). Coudrier and collaborators have suggested coordination between myosin $1 \mathrm{~b}$ and non-muscle myosin II for the scission of tubular carriers at the TGN (Coudrier and Almeida 2011). If this is confirmed, it would represent a new level of cooperation between different actin motors for transport carrier biogenesis. It has been suggested that myosin I could also have sorting ability, which could be linked to its capacity to interact with lipid raft-associated cargo. In this respect, myosin Ic controls the delivery of GPI-linked cargo proteins to the cell surface from the endosomal recycling compartment (Brandstaetter et al. 2012), but this does not seem to be the case for myosin $\mathrm{Ib}$ either at the TGN or in endosomes (Almeida et al. 2011).

Non-muscle myosin II is another non-processive motor that directly interacts with Golgi membranes (Fath 2005; Heimann et al. 1999; Miserey-Lenkei et al. 2010) and mediates both Golgi-to-ER and post-Golgi protein transport (DePina et al. 2007; Duran et al. 2003; Musch et al. 1997; Stow et al. 1998) (Fig. 2c). It was postulated that this motor is tethered to the cisterna by its tail and to actin filaments by its motor head. Its subsequent motion along actin filaments could provide the force needed to extend Golgi-derived membranes away from the cisterna (Fig. 2a), which could facilitate the functional coupling of membrane scission protein(s), leading to the release of the transport carrier. In accordance with this hypothesis, myosin II forms a complex with Rab6, which facilitates its localization to Golgi membranes and controls the fission of anterograde and retrograde Rab6 transport carriers (Miserey-Lenkei et al. 2010). The Golgi-associated tropomyosin isoform
308

309

310

311

312

313

314

315

316

317

318

319

320

321

322

323

324

325

326

327

328

329

330

331

332

333

334

335

336

337

338

339

340

341

342

343

344

345

346

347

348

349

350

351

352

353

354

355 
(Percival et al. 2004) could stabilize short actin filaments formed locally in the cisternae lateral rims during vesicle biogenesis. These short actin filaments together with myosin II could equivalently act as a sarcomeric-like system to generate the force necessary to split transport carriers (Fig. 2a). Accordingly, there is an abnormal accumulation of uncoated vesicles close to cisternae after the knockdown of myosin II or the pharmacological blockade of its motor activity (Duran et al. 2003; Storrie et al. 2012) (Fig. 3). Many of them still remained attached to cisternae (see red arrows in Fig. 3), which argues in favor of the participation of myosin II in the fission process (Miserey-Lenkei et al. 2010). However, in another line of evidence, myosin II has been reported to be required only for motion but not for the biogenesis of PKD-dependent transport carriers at the TGN (Wakana et al. 2012).

In contrast to endocytic recycling and translocation of secretory vesicles/granules to cell periphery actin cytoskeleton, there is no clear experimental evidence of myosin
$\mathrm{V}$ activity at the Golgi in mammalian cells (not the case in yeast; see below). However, a yeast two-hybrid screen of human Rab proteins for myosin Va binding has revealed that myosin $\mathrm{Va}$ isoform functions in post-Golgi-trafficking interacting with Rab6 together with Rab8 and/or Rab10, although myosin Va does not localize in the Golgi (B. Goud, personal communication).

Myosin VI is another myosin motor located in the Golgi (Buss et al. 2004; Warner et al. 2003) (Fig. 2c). It differs from the other processive myosins in that it only moves transport carriers toward the fast-depolymerizing minus-end pole of the microfilament. Therefore, myosin VI could provide the force and directionality for the transport carrier movement away from cisternae in accordance with the expected fastgrowing plus-end polarization of the actin filaments originating in Golgi membranes. Myosin VI is involved, among many others (Buss and Kendrick-Jones 2008; Sweeney and Houdusse 2010), in the maintenance of Golgi morphology (Sahlender et al. 2005; Warner et al. 2003). The interaction
375

376

377

378

379

380

381

382

383

384

385

386

387

388

389

390

391

392

393

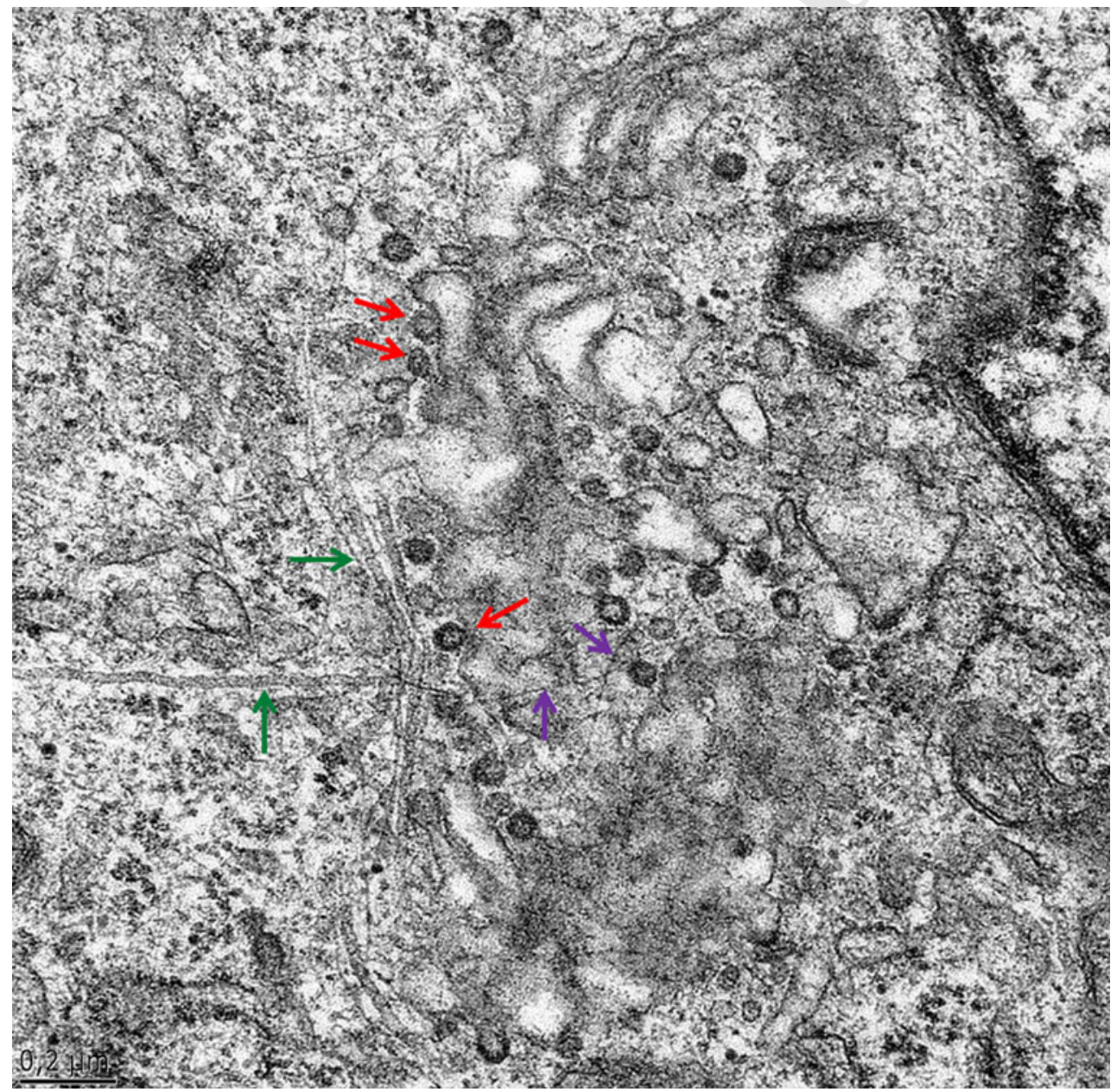

Fig. 3 The pharmacological blockade of the myosin II motor activity by blebblistatin in NRK cells produces an accumulation of peri-Golgi vesicles close to swollen cisternae. Note that some vesicles remain connected to cisternae by a narrow neck (red arrows). Microtubules and actin filaments are, respectively, indicated by green and purple arrows. Bar $200 \mathrm{~nm}$

\begin{tabular}{|l|lll|}
\hline & Journal $:$ Large 418 & Dispatch : 24-6-2013 & Pages : 14 \\
Article No. : 1115 & $\square$ LE & $\square$ TYPESET \\
MS Code : HCB-2664-13-Roth & $\sim_{\mathrm{CP}}$ & $\checkmark_{\text {DISK }}$ \\
\hline
\end{tabular}


between myosin VI and optineurin, a partner of Rab8 (Sahlender et al. 2005), acts at the TGN of polarized epithelial cells in the protein sorting and basolateral transport mediated by the clathrin adaptor protein complex AP-1B (Ang et al. 2003; Au et al. 2007; Jordens et al. 2005). Therefore, the known role of some Rab proteins as linkers of endocytic membranes to cytoskeletal motors is now also extended to the Golgi (Goud and Gleeson 2010).

Finally, the unconventional myosin 18A has also been located in distal Golgi membranes (Fig. 2c), where it binds to the PI4P-binding protein GOLPH3. It has been suggested that the GOLPH3-Myos18 interaction couples actin filaments to Golgi membranes and the tension generated by this interaction facilitates the maintenance of the extended Golgi ribbon organization and flattens Golgi cisternae (Fig. 2a). In addition, it also seems to support secretory function because the depletion of GOLPH3 blocks the exit of VSV-G from the TGN (Dippold et al. 2009). The contribution of this unconventional myosin- to Golgi-associated membrane trafficking requires further characterization because it exhibits low motor activity (Guzik-Lendrum et al. 2013).

\section{The Golgi apparatus-actin interaction in other cellular models}

\section{Plant cells}

Stationary actin filaments or actin bundles are the most prominent cytoskeleton element in plant cells. They are all oriented with the same polarity and aligned along the plant cell. Attached to the actin bundles are the ER, vesicles and numerous discrete or a few clustered Golgi stack-TGN units, also known as Golgi bodies. They are highly variable in number (from a few tens to hundreds) depending on the plant type, plant cell type and its developmental stage (Boutte et al. 2007; Hawes and Satiat-Jeunemaitre 2005; Kepes et al. 2005). In polarized root hairs and pollen tubes, the TGN is segregated from Golgi bodies, which localize to growing tips, where together with actin, Rho/Rac members (ROPs and Rac1, respectively), Rab (Rab4a and Rab11) and ARF (ARF1) small GTPases regulate secretory and endocytic trafficking (Samaj et al. 2006). Also in this cell type, the motility and positioning of Golgi bodies is highly dependent on the actin organization, being faster and directional in areas containing actin filament bundles and slower and non-directional in areas with fine filamentous actin (Akkerman et al. 2011).

In plants, most of the endomembrane compartments are in constant movement together with the cytoplasmic streaming whereby cellular metabolites are distributed throughout the cell (Shimmen and Yokota 2004). Golgi bodies show actin-dependent dispersal and spatial organization (Boevink et al. 1998) and contain a fine fibrillar material enriched in actin, spectrin- and myosin-like proteins (Mollenhauer and Morre 1976; Satiat-Jeunemaitre et al. 1996). The depolymerization of actin filaments with actin toxins uncouples the association between specific regions of cortical ER with individual Golgi bodies (Boevink et al. 1998; Brandizzi et al. 2003), but, and in contrast to animal cells (Valderrama et al. 2001), it does not perturb the brefeldin A (BFA)-induced Golgi disassembly (Ito et al. 2012). Thus, cytochalasin or latrunculin treatments induce the aggregation of Golgi bodies and variably alter the Golgi morphology depending on the cell type and the period of treatment (Chen et al. 2006; SatiatJeunemaitre et al. 1996). Actin toxins also perturb the coordinated movement of Golgi bodies and ER tubules (da Silva et al. 2004; Uemura et al. 2002; Yang et al. 2005). Actin does not participate in the ER/Golgi interface protein transport (Saint-Jore et al. 2002), but it does contribute to post-Golgi trafficking to the plasma membrane and the vacuole. In the tip of growing cells like pollen tubes, actin filaments are the tracks through which Golgi-derived secretory vesicles are transported (Picton and Steer 1981; Vidali et al. 2001). An intact actin-myosin system is required for the transport of cargo containing polysaccharides and the enzymes necessary for cell wall morphogenesis, and the local differences in the actin cytoskeleton organization determine where their secretion is required (Blancaflor 2002; Crowell et al. 2009; Hu et al. 2003; Kato et al. 2010; Miller et al. 1995; Nebenfuhr et al. 1999). Finally, Golgi bodies are propelled by plant myosin family members, especially the myosin XI class (Avisar et al. 2008, 2009; Boutte et al. 2007; Higaki et al. 2007; Peremyslov et al. 2010; Sparkes 2011).

Yeast

The use of a large number of mutants that alter intracellular traffic in the budding yeast $S$. cerevisiae has led to the identification of proteins involved in both membrane trafficking and actin organization (Kaksonen et al. 2006; Mulholland et al. 1997). Most components of the secretory pathway and many of the actin-based cytoskeleton are conserved between yeast and mammalian cells. The actin cytoskeleton in yeast consists primarily of cortical patches and cables (Moseley and Goode 2006). Actin filaments polarize growth in yeast (Novick and Botstein 1985). In this respect, many actin mutants accumulate large secretory vesicles and exhibit phenotypes consistent with defects in polarized growth (Pruyne et al. 2004). This, together with the polarized organization of actin cytoskeleton, has suggested a role for actin in the positioning and orientation of the secretory pathway and polarized transport of late 
secretory vesicles to the plasma membrane (Finger and Novick 2000; Mulholland et al. 1997; Yamaguchi and Kopecka 2010). A mutation of GRD20, a protein involved in sorting in the TGN/endosomal system, showed aberrant secretion of the vacuolar hydrolase carboxypeptidase $\mathrm{Y}$ (but not other TGN membrane proteins) and defects in the polarization of the actin cytoskeleton (Spelbrink and Nothwehr 1999). As in mammalian cells, the actin-severing protein cofilin concomitantly with Pmr1, the yeast orthologue of the secretory pathway calcium ATPase 1 (SPCA1), is also required for sorting at the late Golgi compartment (Curwin et al. 2012). Overexpression of Avl9p, a member of a novel protein superfamily, produces vesicle accumulation and a post-Golgi defect in secretion. Its depletion in a strain that also lacks Vps1 (dynamin) and Apl2 (adaptor protein complex 1) results in perturbed actin cytoskeleton organization and defects in polarized secretion (Harsay and Schekman 2007). Concentration of late (but not early) Golgi elements at the sites of polarized growth (the bud) depends on actin, which is transported along actin cables by yeast myosin V (Myo2) (Rossanese et al. 2001). Crucial in this process is Ypt11, a Rab GTPase that interacts with Myo2 and Ret2, a subunit of the coatomer complex. The polarization of late Golgi cisternae in the bud is not produced in Ypt11 $\Delta$ mutant (Arai et al. 2008). The Rab protein Ypt31/32 present at the TGN directly interacts with Myo 2 and the secretory vesicle Rab Sec4, whose interaction is modulated by PI4P levels (Santiago-Tirado et al. 2011). Moreover, the Ypt31/32Myo2-Sec4 complex interacts with exocyst subunit Sec15 regulating post-Golgi trafficking and cell growth (Jin et al. 2011).

With regard to the early secretory pathway, actin filament depolymerization with actin toxins does not affect anterograde ER-to-Golgi protein transport (Brazer et al. 2000). However, this is not the case in retrograde Golgi-toER trafficking, which is regulated by the ubiquitin ligase Rsp5, a protein that forms a complex containing COPI subunits and has as substrates the actin cytoskeleton proteins Sla1, Lsb1, Lsb2, which bind to the Arp2/3 activator Las17 (Jarmoszewicz et al. 2012; Kaminska et al. 2011).

\section{Drosophila}

The Drosophila cellular model is an alternative to yeast to study the Golgi because it shares many structural and functional similarities with the mammalian model, although most Drosophila cells and tissues lack the characteristic mammalian Golgi ribbon. Instead, they present a scattered and fairly constant number of what are known as tER-Golgi units, which are ultrastructurally constituted by a pair of Golgi stacks (Kondylis and Rabouille 2009). The integrity of the actin cytoskeleton is crucial for Golgi stack pairs since actin depolymerization causes their splitting and perturbs Golgi inheritance, which requires duplication to form the paired structure. Abi and Scar/WAVE (but not WASP) are necessary in this process (Kondylis et al. 2007). The inactivation of the golgin-like microtubule/actinbinding protein lava lamp prevented the necessary Golgi dispersal in the cellularization process (Papoulas et al. 2005; Sisson et al. 2000). The analysis of a genome-wide RNA-mediated interference screen in adherent Drosophila S2 cells showed that the depletion of the $t s r$ gene (which codifies for destrin, also known as ADF/cofilin) induces Golgi membranes to aggregate and swell, resulting in inhibition of the HRP secretion (Bard et al. 2006). Coronin proteins dpdo1 and coro regulate the actin cytoskeleton and also govern biosynthetic and endocytic vesicular trafficking, as indicated by mutant phenotypes that show severe developmental defects, ranging from abnormal cell division to aberrant formation of morphogen gradients (Rybakin and Clemen 2005).

\section{Dictyostelium discoideum}

Cells of this social amoeba are easy to manipulate by genetic and biochemical means. They contain various types of vacuole, ER and small Golgi stacks (Becker and Melkonian 1996). Comitin (p24) is a dimeric Dictyostelium actin-binding protein present in the Golgi and vesicles that contains sequence motifs homologous to lectins. It seems that this protein binds Golgi-derived vesicles to the actin filaments via the cytoplasmic exposed mannosylated glycans (Jung et al. 1996; Weiner et al. 1993). Villidin is another actin-binding protein that associates with secretory vesicles and Golgi membranes (Gloss et al. 2003). The centrosomal protein LIS1 (DdLIS1) links microtubules, the nucleus and the centrosome and indirectly controls the Golgi morphology. Mutants of this protein lead to microtubule disruption, Golgi fragmentation and actin depolymerization (Rehberg et al. 2005). AmpA is a secreted protein necessary for cell migration in an environmentdependent manner that also participates in the regulation of actin polymerization. It is found in the Golgi but transported to the plasma membrane, where it regulates endocytosis (Noratel et al. 2012). In addition to Rho GTPases, Dictyostelium also contains other Rho-regulated signaling components such as RhoGDI, Arp2/3 complex, PAK, WASP, Scar/WAVE, formins, GEFS and GAPS (Eichinger et al. 2005). The acquisition of cell polarity during chemotaxis needs WASP, which localizes on vesicles whose formation in the Golgi requires the interaction between WASP with the pombe Cdc15 homology (PCH) family protein members Nwk/Bzz1-p-like and syndapin-like proteins (Lee et al. 2009). RacH is a closer protein to Rac and $\mathrm{Cdc} 42$ which localizes to compartments of the secretory

\begin{tabular}{|l|lll|}
\hline Journal : Large 418 & Dispatch : 24-6-2013 & Pages : 14 \\
Article No. : 1115 & $\square$ & $\square$ TYPESET \\
MS Code : HCB-2664-13-Roth & $\sim_{\text {CP }}$ & $\checkmark$ DISK \\
\hline
\end{tabular}


pathway (nuclear envelope, ER and the Golgi) where it stimulates actin polymerization, and it also seems to be involved in actin-based trafficking of vesicles, but in contrast to AmpA, it is uncoupled from chemotaxis (Somesh et al. 2006).

\section{Caenorhabditis elegans}

Very little is known about the Golgi and actin cytoskeleton interaction in this organism, but consistent with a possible role of coronin 7 in Golgi trafficking (Rybakin et al. 2004; Rybakin and Clemen 2005), depletion of the coronin 7 homolog POD1 leads to aberrant accumulation of vesicles in cells of the early embryo (Rappleye et al. 1999). Moreover, CRP-1, a Cdc42-related protein, localizes at the TGN and recycling endosomes. Alteration of CRP-1 expression in epithelial-like cells perturbs apical but not basolateral trafficking (Jenna et al. 2005).

\section{Concluding remarks and perspectives}

The actin cytoskeleton usually works in tight coordination with microtubules (Disanza and Scita 2008). The functional relationship between each cytoskeleton network and Golgi dynamics is complementary. In animal cells, actin and co-workers participate in early events of transport biogenesis such as protein sorting, membrane fission and keeping cisternae flat. Microtubules and associated motors are more directly involved in the motion of Golgi-derived transport carriers to their final destinations and in the positioning and organization of the Golgi as a ribbon-like structure (at least in vertebrates) (Brownhill et al. 2009; de Forges et al. 2012). Conversely, in plant cells, endomembrane compartments and associated trafficking are almost exclusively mediated by actin filaments. In other cellular models, less is known but in general terms, actin cytoskeleton elements regularly participate in post-Golgi protein transport and Golgi inheritance. Finally, the actin cytoskeleton as a dynamic biopolymer surely affects the biophysical properties (rigidity/elasticity and tension) of Golgi membranes. Future research in this biophysical cell biology interactive area will undoubtedly provide valuable information about how actin contributes to the structural and functional organization of the Golgi. Another important question is how myosin motors participate in the genesis of transport carriers, particularly in providing the force that generates curvature and facilitates membrane fission. In vitro models such as the giant unilamellar vesicles (GUVs) (Bassereau and Goud 2011) will help to our knowledge of the precise molecular mechanism and sequence of this process. According to the evidence furnished by this particular line of research, curved membranes, but not flat ones, use phosphoinositides to stimulate Cdc42-N-WASP-Arp2/3-driven actin polymerization (Gallop et al. 2013). Finally, the results that clearly implicate actin in protein sorting and the identification of molecular targets that directly regulate the ionic environment of the TGN/Golgi provide an unexpected new perspective on the Golgi-cytoskeleton interaction.

Acknowledgments G.E. thanks current and past members of his laboratory for their support, good work and stimulating discussions, and many friends and colleagues for suggestions, criticisms and/or reagents that altogether have contributed to the progress in our research in this field. G.E. also thanks Darya Gorbenko, Rosa M. Ríos and Bruno Goud for critical reading of the manuscript, and Robin Rycroft for his invaluable editorial assistance. Carla Serra, Enric Gutiérrez and Laia Salcedo-Sicilia are recipients of predoctoral fellowships from the Spanish or Catalonian Science agencies. The work carried out in our laboratory has been regularly supported by grants from Spanish government.

\section{References}

Akkerman M, Overdijk EJ, Schel JH, Emons AM, Ketelaar T (2011) Golgi body motility in the plant cell cortex correlates with actin cytoskeleton organization. Plant Cell Physiol 52:1844-1855

Almeida CG, Yamada A, Tenza D, Louvard D, Raposo G, Coudrier E (2011) Myosin 1b promotes the formation of post-Golgi carriers by regulating actin assembly and membrane remodelling at the trans-Golgi network. Nat Cell Biol 13:779-789

Ang AL, Folsch H, Koivisto UM, Pypaert M, Mellman I (2003) The Rab8 GTPase selectively regulates AP-1B-dependent basolateral transport in polarized Madin-Darby canine kidney cells. J Cell Biol 163:339-350

Anitei M, Stange C, Parshina I, Baust T, Schenck A, Raposo G, Kirchhausen T, Hoflack B (2010) Protein complexes containing CYFIP/Sra/PIR121 coordinate Arf1 and Rac1 signalling during clathrin-AP-1-coated carrier biogenesis at the TGN. Nat Cell Biol 12:330-340

Arai S, Noda Y, Kainuma S, Wada I, Yoda K (2008) Ypt11 functions in bud-directed transport of the Golgi by linking Myo2 to the coatomer subunit Ret2. Curr Biol 18:987-991

Au JS, Puri C, Ihrke G, Kendrick-Jones J, Buss F (2007) Myosin VI is required for sorting of $\mathrm{AP}-1 \mathrm{~B}$-dependent cargo to the basolateral domain in polarized MDCK cells. J Cell Biol 177:103-114

Avisar D, Prokhnevsky AI, Makarova KS, Koonin EV, Dolja VV (2008) Myosin XI-K Is required for rapid trafficking of Golgi stacks, peroxisomes, and mitochondria in leaf cells of Nicotiana benthamiana. Plant Physiol 146:1098-1108

Avisar D, Abu-Abied M, Belausov E, Sadot E, Hawes C, Sparkes IA (2009) A comparative study of the involvement of 17 Arabidopsis myosin family members on the motility of Golgi and other organelles. Plant Physiol 150:700-709

Bard F, Casano L, Mallabiabarrena A, Wallace E, Saito K, Kitayama H, Guizzunti G, Hu Y, Wendler F, Dasgupta R, Perrimon N, Malhotra V (2006) Functional genomics reveals genes involved in protein secretion and Golgi organization. Nature 439:604-607

Bassereau P, Goud B (2011) Physics, biology and the right chemistry. F1000 Biol Rep 3:7

Beck KA, Nelson WJ (1998) A spectrin membrane skeleton of the Golgi complex. Biochim Biophys Acta 1404:153-160

$\begin{array}{ll}\text { Dispatch : 24-6-2013 } & \text { Pages : } \mathbf{1 4} \\ \square \text { LE } & \\ \boldsymbol{C}_{\mathrm{CP}} & \square \text { TYPESET } \\ \end{array}$


Beck KA, Buchanan JA, Malhotra V, Nelson WJ (1994) Golgi spectrin: identification of an erythroid beta-spectrin homolog associated with the Golgi complex. J Cell Biol 127:707-723

Beck KA, Buchanan JA, Nelson WJ (1997) Golgi membrane skeleton: identification, localization and oligomerization of a $195 \mathrm{kDa}$ ankyrin isoform associated with the Golgi complex. J Cell Sci 110:1239-1249

Becker B, Melkonian M (1996) The secretory pathway of protists: spatial and functional organization and evolution. Microbiol Rev 60:697-721

Blancaflor EB (2002) The cytoskeleton and gravitropism in higher plants. J Plant Growth Regul 21:120-136

Boevink P, Oparka K, Santa Cruz S, Martin B, Betteridge A, Hawes C (1998) Stacks on tracks: the plant Golgi apparatus traffics on an actin/ER network. Plant J 15:441-447

Boutte Y, Vernhettes S, Satiat-Jeunemaitre B (2007) Involvement of the cytoskeleton in the secretory pathway and plasma membrane organisation of higher plant cells. Cell Biol Int 31:649-654

Brandizzi F, Saint-Jore C, Moore I, Hawes C (2003) The relationship between endomembranes and the plant cytoskeleton. Cell Biol Int 27:177-179

Brandstaetter H, Kendrick-Jones J, Buss F (2012) Myo1c regulates lipid raft recycling to control cell spreading, migration and Salmonella invasion. J Cell Sci 125:1991-2003

Brazer SC, Williams HP, Chappell TG, Cande WZ (2000) A fission yeast kinesin affects Golgi membrane recycling. Yeast 16:149-166

Brownhill K, Wood L, Allan V (2009) Molecular motors and the Golgi complex: staying put and moving through. Semin Cell Dev Biol 20(7):784-792

Buss F, Kendrick-Jones J (2008) How are the cellular functions of myosin VI regulated within the cell? Biochem Biophys Res Commun 369:165-175

Buss F, Spudich G, Kendrick-Jones J (2004) Myosin VI: cellular functions and motor properties. Annu Rev Cell Dev Biol 20:649-676

Camera P, da Silva JS, Griffiths G, Giuffrida MG, Ferrara L, Schubert V, Imarisio S, Silengo L, Dotti CG, Di Cunto F (2003) Citron-N is a neuronal Rho-associated protein involved in Golgi organization through actin cytoskeleton regulation. Nat Cell Biol 5:1071-1078

Campellone KG, Welch MD (2010) A nucleator arms race: cellular control of actin assembly. Nat Rev Mol Cell Biol 11:237-251

Campellone KG, Webb NJ, Znameroski EA, Welch MD (2008) WHAMM is an Arp2/3 complex activator that binds microtubules and functions in ER to Golgi transport. Cell 134:148-161

Cao H, Weller S, Orth JD, Chen J, Huang B, Chen JL, Stamnes M, McNiven MA (2005) Actin and Arf1-dependent recruitment of a cortactin-dynamin complex to the Golgi regulates post-Golgi transport. Nat Cell Biol 7:483-492

Carreno S, Engqvist-Goldstein AE, Zhang CX, McDonald KL, Drubin DG (2004) Actin dynamics coupled to clathrin-coated vesicle formation at the trans-Golgi network. J Cell Biol 165:781-788

Chen JL, Lacomis L, Erdjument-Bromage H, Tempst P, Stamnes M (2004) Cytosol-derived proteins are sufficient for Arp2/3 recruitment and ARF/coatomer-dependent actin polymerization on Golgi membranes. FEBS Lett 566:281-286

Chen JL, Fucini RV, Lacomis L, Erdjument-Bromage H, Tempst P, Stamnes M (2005) Coatomer-bound Cdc42 regulates dynein recruitment to COPI vesicles. J Cell Biol 169:383-389

Chen Y, Chen T, Shen S, Zheng M, Guo Y, Lin J, Baluska F, Samaj J (2006) Differential display proteomic analysis of Picea meyeri pollen germination and pollen-tube growth after inhibition of actin polymerization by latrunculin B. Plant J 47:174-195
Cohen D, Musch A, Rodriguez-Boulan E (2001) Selective control of basolateral membrane protein polarity by cdc 42 . Traffic 2:556-564

Colon-Franco JM, Gomez TS, Billadeau DD (2011) Dynamic remodeling of the actin cytoskeleton by FMNL1 $\gamma$ is required for structural maintenance of the Golgi complex. J Cell Sci 124:3118-3126

Coudrier E, Almeida CG (2011) Myosin 1 controls membrane shape by coupling F-Actin to membrane. Bioarchitecture 1:230-235

Crowell EF, Bischoff V, Desprez T, Rolland A, Stierhof YD, Schumacher K, Gonneau M, Hofte H, Vernhettes S (2009) Pausing of Golgi bodies on microtubules regulates secretion of cellulose synthase complexes in Arabidopsis. Plant cell 21:1141-1154

Curwin AJ, von Blume J, Malhotra V (2012) Cofilin-mediated sorting and export of specific cargo from the Golgi apparatus in yeast. Mol Biol Cell 23:2327-2338

daSilva LL, Snapp EL, Denecke J, Lippincott-Schwartz J, Hawes C, Brandizzi F (2004) Endoplasmic reticulum export sites and Golgi bodies behave as single mobile secretory units in plant cells. Plant Cell 16:1753-1771

de Forges H, Boussou A, Perez F (2012) Interplay between microtubule dynamics and intracellular organization. Int $\mathrm{J}$ Biochem Cell Biol 44:266-274

De Matteis MA, Morrow JS (2000) Spectrin tethers and mesh in the biosynthetic pathway. J Cell Sci 113:2331-2343

DePina AS, Wollert T, Langford GM (2007) Membrane associated nonmuscle myosin II functions as a motor for actin-based vesicle transport in clam oocyte extracts. Cell Motil Cytoskeleton 64:739-755

Devarajan P, Stabach PR, Mann AS, Ardito T, Kashgarian M, Morrow JS (1996) Identification of a small cytoplasmic ankyrin (AnkG119) in the kidney and muscle that binds beta I sigma spectrin and associates with the Golgi apparatus. J Cell Biol 133:819-830

Devarajan P, Stabach PR, De Matteis MA, Morrow JS (1997) Na, K-ATPase transport from endoplasmic reticulum to Golgi requires the Golgi spectrin-ankyrin G119 skeleton in Madin Darby canine kidney cells. Proc Natl Acad Sci USA 94:10711-10716

di Campli A, Valderrama F, Babia T, De Matteis MA, Luini A, Egea G (1999) Morphological changes in the Golgi complex correlate with actin cytoskeleton rearrangements. Cell Motil Cytoskeleton 43:334-348

Dippold HC, Ng MM, Farber-Katz SE, Lee SK, Kerr ML, Peterman MC, Sim R, Wiharto PA, Galbraith KA, Madhavarapu S, Fuchs GJ, Meerloo T, Farquhar MG, Zhou H, Field SJ (2009) GOLPH3 bridges phosphatidylinositol-4-phosphate and actomyosin to stretch and shape the Golgi to promote budding. Cell 139:337-351

Disanza A, Scita G (2008) Cytoskeletal regulation: coordinating actin and microtubule dynamics in membrane trafficking. Curr Biol 18:R873-R875

Dubois T, Paleotti O, Mironov AA, Fraisier V, Stradal TE, De Matteis MA, Franco M, Chavrier P (2005) Golgi-localized GAP for Cdc42 functions downstream of ARF1 to control Arp2/3 complex and F-actin dynamics. Nat Cell Biol 7:353-364

Duran JM, Valderrama F, Castel S, Magdalena J, Tomas M, Hosoya H, Renau-Piqueras J, Malhotra V, Egea G (2003) Myosin motors and not actin comets are mediators of the actin-based Golgi-toendoplasmic reticulum protein transport. Mol Biol Cell 14:445-459

Egea G, Rios RM (2008) The role of the cytoskeleton in the structure and function of the Golgi apparatus. In: Mironov AA, Pavelka M (eds) The Golgi apparatus-state of the art 110 years after

\begin{tabular}{|l|lll|}
\hline & Journal : Large 418 & Dispatch : 24-6-2013 & Pages : 14 \\
Article No. : $\mathbf{1 1 1 5}$ & $\square$ LE & $\square$ TYPESET \\
MS Code : HCB-2664-13-Roth & $\sim_{\mathrm{CP}}$ & $\boldsymbol{\sim}$ DISK \\
\hline
\end{tabular}


Camillo Golgi's discovery. Springer Wien, New York, pp 270-300

Egea G, Lazaro-Dieguez F, Vilella M (2006) Actin dynamics at the Golgi complex in mammalian cells. Curr Opin Cell Biol 18:168-178

Egorov MV, Capestrano M, Vorontsova OA, Di Pentima A, Egorova AV, Mariggio S, Ayala MI, Tete S, Gorski JL, Luini A, Buccione R, Polishchuk RS (2009) Faciogenital dysplasia protein (FGD1) regulates export of cargo proteins from the Golgi complex via Cdc42 activation. Mol Biol Cell 20: 2413-2427

Eichinger L, Pachebat JA, Glockner G et al (2005) The genome of the social amoeba Dictyostelium discoideum. Nature 435:43-57

Erickson JW, Zhang C, Kahn RA, Evans T, Cerione RA (1996) Mammalian Cdc42 is a brefeldin A-sensitive component of the Golgi apparatus. J Biol Chem 271:26850-26854

Estrada L, Caron E, Gorski JL (2001) Fgd1, the Cdc42 guanine nucleotide exchange factor responsible for faciogenital dysplasia, is localized to the subcortical actin cytoskeleton and Golgi membrane. Hum Mol Genet 10:485-495

Fath KR (2005) Characterization of myosin-II binding to Golgi stacks in vitro. Cell Motil Cytoskeleton 60:222-235

Fath KR, Burgess DR (1993) Golgi-derived vesicles from developing epithelial cells bind actin filaments and possess myosin-I as a cytoplasmically oriented peripheral membrane protein. J Cell Biol 120:117-127

Finger FP, Novick P (2000) Synthetic interactions of the post-Golgi sec mutations of Saccharomyces cerevisiae. Genetics 156:943-951

Fucini RV, Navarrete A, Vadakkan C, Lacomis L, ErdjumentBromage H, Tempst P, Stamnes M (2000) Activated ADPribosylation factor assembles distinct pools of actin on Golgi membranes. J Biol Chem 275:18824-18829

Gad AK, Nehru V, Ruusala A, Aspenstrom P (2012) RhoD regulates cytoskeletal dynamics via the actin nucleation-promoting factor WASp homologue associated with actin Golgi membranes and microtubules. Mol Biol Cell 23(24):4807-4819

Gallop JL, Walrant A, Cantley LC, Kirschner MW (2013) Phosphoinositides and membrane curvature switch the mode of actin polymerization via selective recruitment of toca-1 and Snx9. Proc Natl Acad Sci USA 110:7193-7198

Gao Y, Sztul E (2001) A novel interaction of the Golgi complex with the vimentin intermediate filament cytoskeleton. J Cell Biol 152:877-894

Gao YS, Vrielink A, MacKenzie R, Sztul E (2002) A novel type of regulation of the vimentin intermediate filament cytoskeleton by a Golgi protein. Eur J Cell Biol 81:391-401

Gloss A, Rivero F, Khaire N, Muller R, Loomis WF, Schleicher M, Noegel AA (2003) Villidin, a novel WD-repeat and villin-related protein from Dictyostelium, is associated with membranes and the cytoskeleton. Mol Biol Cell 14:2716-2727

Godi A, Santone I, Pertile P, Devarajan P, Stabach PR, Morrow JS, Di Tullio G, Polishchuk R, Petrucci TC, Luini A, De Matteis MA (1998) ADP ribosylation factor regulates spectrin binding to the Golgi complex. Proc Natl Acad Sci USA 95:8607-8612

Gomez TS, Billadeau DD (2009) A FAM21-containing WASH complex regulates retromer-dependent sorting. Dev Cell 17:699-711

Goud B, Gleeson PA (2010) TGN golgins, Rabs and cytoskeleton: regulating the Golgi trafficking highways. Trends Cell Biol 20:329-336

Guerriero CJ, Weixel KM, Bruns JR, Weisz OA (2006) Phosphatidylinositol 5-kinase stimulates apical biosynthetic delivery via an Arp2/3-dependent mechanism. J Biol Chem 281: 15376-15384
Guzik-Lendrum S, Heissler SM, Billington N, Takagi Y, Yang Y, Knight PJ, Homsher E, Sellers JR (2013) Mammalian myosin18A, a highly divergent myosin. J Biol Chem 288:9532-9548

Harris KP, Tepass U (2010) Cdc42 and vesicle trafficking in polarized cells. Traffic 11:1272-1279

Harsay E, Schekman R (2007) Av19p, a member of a novel protein superfamily, functions in the late secretory pathway. Mol Biol Cell 18:1203-1219

Hawes C, Satiat-Jeunemaitre B (2005) The plant Golgi apparatusgoing with the flow. Biochim Biophys Acta 1744:93-107

He CY (2007) Golgi biogenesis in simple eukaryotes. Cell Microbiol 9:566-572

He CY, Ho HH, Malsam J, Chalouni C, West CM, Ullu E, Toomre D, Warren G (2004) Golgi duplication in Trypanosoma brucei. J Cell Biol 165:313-321

Hehnly H, Stamnes M (2007) Regulating cytoskeleton-based vesicle motility. FEBS Lett 581:2112-2118

Hehnly H, Longhini KM, Chen JL, Stamnes M (2009) Retrograde Shiga toxin trafficking is regulated by ARHGAP21 and Cdc42. Mol Biol Cell 20:4303-4312

Heimann K, Percival JM, Weinberger R, Gunning P, Stow JL (1999) Specific isoforms of actin-binding proteins on distinct populations of Golgi-derived vesicles. J Biol Chem 274:10743-10750

Henderson GP, Gan L, Jensen GJ (2007) 3-D ultrastructure of $O$. tauri: electron cryotomography of an entire eukaryotic cell. PLoS One 2:e749

Heuvingh J, Franco M, Chavrier P, Sykes C (2007) ARF1-mediated actin polymerization produces movement of artificial vesicles. Proc Natl Acad Sci USA 104:16928-16933

Higaki T, Sano T, Hasezawa S (2007) Actin microfilament dynamics and actin side-binding proteins in plants. Curr Opin Plant Biol 10:549-556

Holappa K, Suokas M, Soininen P, Kellokumpu S (2001) Identification of the full-length AE2 (AE2a) isoform as the Golgiassociated anion exchanger in fibroblasts. J Histochem Cytochem 49:259-269

Holappa K, Munoz MT, Egea G, Kellokumpu S (2004) The AE2 anion exchanger is necessary for the structural integrity of the Golgi apparatus in mammalian cells. FEBS Lett 564:97-103

Holleran EA, Holzbaur EL (1998) Speculating about spectrin: new insights into the Golgi-associated cytoskeleton. Trends Cell Biol 8:26-29

Holleran EA, Ligon LA, Tokito M, Stankewich MC, Morrow JS, Holzbaur EL (2001) Beta III spectrin binds to the Arp1 subunit of dynactin. J Biol Chem 276:36598-36605

$\mathrm{Hu}$ Y, Zhong R, Morrison WH 3rd, Ye ZH (2003) The Arabidopsis RHD3 gene is required for cell wall biosynthesis and actin organization. Planta 217:912-921

Ito Y, Uemura T, Shoda K, Fujimoto M, Ueda T, Nakano A (2012) cis-Golgi proteins accumulate near the ER exit sites and act as the scaffold for Golgi regeneration after brefeldin A treatment in tobacco BY-2 cells. Mol Biol Cell 23:3203-3214

Jacob R, Heine M, Alfalah M, Naim HY (2003) Distinct cytoskeletal tracks direct individual vesicle populations to the apical membrane of epithelial cells. Curr Biol 13:607-612

Jarmoszewicz K, Lukasiak K, Riezman H, Kaminska J (2012) Rsp5 ubiquitin ligase is required for protein trafficking in Saccharomyces cerevisiae COPI mutants. PLoS One 7:e39582

Jenna S, Caruso ME, Emadali A, Nguyen DT, Dominguez M, Li S, Roy R, Reboul J, Vidal M, Tzimas GN, Bosse R, Chevet E (2005) Regulation of membrane trafficking by a novel Cdc42related protein in Caenorhabditis elegans epithelial cells. Mol Biol Cell 16:1629-1639

Jin Y, Sultana A, Gandhi P, Franklin E, Hamamoto S, Khan AR, Munson M, Schekman R, Weisman LS (2011) Myosin V 
transports secretory vesicles via a Rab GTPase cascade and interaction with the exocyst complex. Dev Cell 21:1156-1170

Jordens I, Marsman M, Kuijl C, Neefjes J (2005) Rab proteins, connecting transport and vesicle fusion. Traffic 6:1070-1077

Jung E, Fucini P, Stewart M, Noegel AA, Schleicher M (1996) Linking microfilaments to intracellular membranes: the actinbinding and vesicle-associated protein comitin exhibits a mannose-specific lectin activity. EMBO J 15:1238-1246

Kaksonen M, Toret CP, Drubin DG (2006) Harnessing actin dynamics for clathrin-mediated endocytosis. Nat Rev Mol Cell Biol 7:404-414

Kaminska J, Spiess M, Stawiecka-Mirota M, Monkaityte R, Haguenauer-Tsapis R, Urban-Grimal D, Winsor B, Zoladek T (2011) Yeast Rsp5 ubiquitin ligase affects the actin cytoskeleton in vivo and in vitro. Eur J Cell Biol 90:1016-1028

Kang Q, Wang T, Zhang H, Mohandas N, An X (2009) A Golgiassociated protein $4.1 \mathrm{~B}$ variant is required for assimilation of proteins in the membrane. J Cell Sci 122:1091-1099

Kato T, Morita MT, Tasaka M (2010) Defects in dynamics and functions of actin filament in Arabidopsis caused by the dominant-negative actin fiz1-induced fragmentation of actin filament. Plant Cell Physiol 51:333-338

Kepes F, Rambourg A, Satiat-Jeunemaitre B (2005) Morphodynamics of the secretory pathway. Int Rev Cytol 242:55-120

Kerkhoff E, Simpson JC, Leberfinger CB, Otto IM, Doerks T, Bork P, Rapp UR, Raabe T, Pepperkok R (2001) The Spir actin organizers are involved in vesicle transport processes. Curr Biol 11:1963-1968

Kessels MM, Qualmann B (2004) The syndapin protein family: linking membrane trafficking with the cytoskeleton. J Cell Sci 117:3077-3086

Kessels MM, Dong J, Leibig W, Westermann P, Qualmann B (2006) Complexes of syndapin II with dynamin II promote vesicle formation at the trans-Golgi network. J Cell Sci 119:1504-1516

Kirkbride KC, Hong NH, French CL, Clark ES, Jerome WG, Weaver AM (2012) Regulation of late endosomal/lysosomal maturation and trafficking by cortactin affects Golgi morphology. Cytoskeleton 69:625-643

Kondylis V, Rabouille C (2003) A novel role for dp115 in the organization of tER sites in Drosophila. J Cell Biol 162:185-198

Kondylis V, Rabouille C (2009) The Golgi apparatus: lessons from Drosophila. FEBS Lett 583:3827-3838

Kondylis V, van Nispen tot Pannerden HE, Herpers B, Friggi-Grelin F, Rabouille C (2007) The Golgi comprises a paired stack that is separated at $\mathrm{G} 2$ by modulation of the actin cytoskeleton through Abi and Scar/WAVE. Dev Cell 12:901-915

Kostenko EV, Mahon GM, Cheng L, Whitehead IP (2005) The Sec14 homology domain regulates the cellular distribution and transforming activity of the Rho-specific guanine nucleotide exchange factor Dbs. J Biol Chem 280:2807-2817

Kroschewski R, Hall A, Mellman I (1999) Cdc42 controls secretory and endocytic transport to the basolateral plasma membrane of MDCK cells. Nat Cell Biol 1:8-13

Ladinsky MS, Mastronarde DN, McIntosh JR, Howell KE, Staehelin LA (1999) Golgi structure in three dimensions: functional insights from the normal rat kidney cell. J Cell Biol 144:1135-1149

Lanzetti L (2007) Actin in membrane trafficking. Curr Opin Cell Biol 19:453-458

Lazaro-Dieguez F, Jimenez N, Barth H, Koster AJ, Renau-Piqueras J, Llopis JL, Burger KN, Egea G (2006) Actin filaments are involved in the maintenance of Golgi cisternae morphology and intra-Golgi pH. Cell Motil Cytoskeleton 63:778-791

Lazaro-Dieguez F, Colonna C, Cortegano M, Calvo M, Martinez SE, Egea G (2007) Variable actin dynamics requirement for the exit of different cargo from the trans-Golgi network. FEBS Lett $581: 3875-3881$
Lebreton S, Paladino S, Zurzolo C (2008) Selective roles for cholesterol and actin in compartmentalization of different proteins in the Golgi and plasma membrane of polarized cells. J Biol Chem 283:29545-29553

Lee S, Han JW, Leeper L, Gruver JS, Chung CY (2009) Regulation of the formation and trafficking of vesicles from Golgi by $\mathrm{PCH}$ family proteins during chemotaxis. Biochim Biophys Acta 1793:1199-1209

Loubéry S, Coudrier E (2008) Myosins in the secretory pathway: tethers or transporters? Cell Mol Life Sci 65:2790-2800

Lowe M (2011) Structural organization of the Golgi apparatus. Curr Cell Biol 23:85-93

Luna A, Matas OB, Martinez-Menarguez JA, Mato E, Duran JM, Ballesta J, Way M, Egea G (2002) Regulation of protein transport from the Golgi complex to the endoplasmic reticulum by CDC42 and N-WASP. Mol Biol Cell 13:866-879

Lux SE (1979) Spectrin-actin membrane skeleton of normal and abnormal red blood cells. Semin Hematol 16:21-51

Matas OB, Martinez-Menarguez JA, Egea G (2004) Association of Cdc42/N-WASP/Arp2/3 signaling pathway with Golgi membranes. Traffic 5:838-846

Matas OB, Fritz S, Luna A, Egea G (2005) Membrane trafficking at the ER/Golgi interface: functional implications of RhoA and Rac1. Eur J Cell Biol 84:699-707

Mazzochi C, Benos DJ, Smith PR (2006) Interaction of epithelial ion channels with the actin-based cytoskeleton. Am J Physiol Renal Physiol 291:F1113-F1122

Menetrey J, Perderiset M, Cicolari J, Dubois T, Elkhatib N, El Khadali F, Franco M, Chavrier P, Houdusse A (2007) Structural basis for ARF1-mediated recruitment of ARHGAP21 to Golgi membranes. EMBO J 26:1953-1962

Merrifield CJ (2004) Seeing is believing: imaging actin dynamics at single sites of endocytosis. Trends Cell Biol 14:352-358

Merrifield CJ, Perrais D, Zenisek D (2005) Coupling between clathrin-coated-pit invagination, cortactin recruitment, and membrane scission observed in live cells. Cell 121:593-606

Miller DD, Scordilis SP, Hepler PK (1995) Identification and localization of three classes of myosins in pollen tubes of Lilium longiflorum and Nicotiana alata. J Cell Sci 108:2549-2563

Miserey-Lenkei S, Chalancon G, Bardin S, Formstecher E, Goud B, Echard A (2010) Rab and actomyosin-dependent fission of transport vesicles at the Golgi complex. Nat Cell Biol 12:645-654

Mogelsvang S, Gomez-Ospina N, Soderholm J, Glick BS, Staehelin LA (2003) Tomographic evidence for continuous turnover of Golgi cisternae in Pichia pastoris. Mol Biol Cell 14:2277-2291

Mollenhauer HH, Morre DJ (1976) Cytochalasin B, but not colchicine, inhibits migration of secretory vesicles in root tips of maize. Protoplasma 87:39-48

Montes de Oca G, Lezama RA, Mondragon R, Castillo AM, Meza I (1997) Myosin I interactions with actin filaments and transGolgi-derived vesicles in MDCK cell monolayers. Arch Med Res 28:321-328

Mooren OL, Galletta BJ, Cooper JA (2012) Roles for actin assembly in endocytosis. Annu Rev Biochem 81:661-686

Moriyama Y, Nelson N (1989) $\mathrm{H}^{+}$-translocating ATPase in Golgi apparatus. Characterization as vacuolar $\mathrm{H}^{+}$-ATPase and its subunit structures. J Biol Chem 264:18445-18450

Moseley JB, Goode BL (2006) The yeast actin cytoskeleton: from cellular function to biochemical mechanism. Microbiol Mol Biol Rev 70:605-645

Mulholland J, Wesp A, Riezman H, Botstein D (1997) Yeast actin cytoskeleton mutants accumulate a new class of Golgi-derived secretary vesicle. Mol Biol Cell 8:1481-1499

Musch A, Cohen D, Rodriguez-Boulan E (1997) Myosin II is involved in the production of constitutive transport vesicles from the TGN. J Cell Biol 138:291-306
1063

1064

1065

1066

1067

1068

1069

1070

1071

1072

1073

1074

1075

1076

1077

1078

1079

1080

1081

1082

1083

1084

1085

1086

1087

1088

1089

1090

1091

1092

\begin{tabular}{|c|c|c|c|c|}
\hline & Journal : Large 418 & Dispatch & 24-6-2013 & Pages: \\
\hline & $\begin{array}{l}\text { Article No. : } 1115 \\
\text { MS Code : } \quad \text { HCB-2664-13-Roth }\end{array}$ & 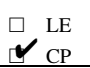 & & $\begin{array}{l}\square \text { TYPESET } \\
\Downarrow \text { DISK } \\
\end{array}$ \\
\hline
\end{tabular}


1093

1094

1095

1096

1097

1098

1099

1100

1101

1102

1103

1104

1105

1106

1107

1108

1109

1110

1111

1112

1113

1114

1115

1116

1117

1118

1119

1120

1121

1122

1123

1124

1125

1126

1127

1128

1129

1130

1131

1132

1133

1134

1135

1136

1137

1138

1139

1140

1141

1142

1143

1144

1145

1146

1147

1148

1149

1150

1151

1152

1153

1154

1155

1156

1157
Musch A, Cohen D, Kreitzer G, Rodriguez-Boulan E (2001) cdc42 regulates the exit of apical and basolateral proteins from the trans-Golgi network. EMBO J 20:2171-2179

Myers KR, Casanova JE (2008) Regulation of actin cytoskeleton dynamics by Arf-family GTPases. Trends Cell Biol 18:184-192

Nakamura N, Tanaka S, Teko Y, Mitsui K, Kanazawa H (2005) Four $\mathrm{Na}^{+} / \mathrm{H}^{+}$exchanger isoforms are distributed to Golgi and postGolgi compartments and are involved in organelle $\mathrm{pH}$ regulation. J Biol Chem 280:1561-1572

Nebenfuhr A, Gallagher LA, Dunahay TG, Frohlick JA, Mazurkiewicz AM, Meehl JB, Staehelin LA (1999) Stop-and-go movements of plant Golgi stacks are mediated by the actomyosin system. Plant Physiol 121:1127-1142

Ng MM, Dippold HC, Buschman MD, Noakes CJ, Field SJ (2013) GOLPH3L antagonizes GOLPH3 to determine Golgi morphology. Mol Biol Cell 24:796-808

Noratel EF, Petty CL, Kelsey JS, Cost HN, Basappa N, Blumberg DD (2012) The adhesion modulation protein, AmpA localizes to an endocytic compartment and influences substrate adhesion, actin polymerization and endocytosis in vegetative Dictyostelium cells. BMC Cell Biol 13:29

Novick P, Botstein D (1985) Phenotypic analysis of temperaturesensitive yeast actin mutants. Cell 40:405-416

Papoulas O, Hays TS, Sisson JC (2005) The golgin Lava lamp mediates dynein-based Golgi movements during Drosophila cellularization. Nat Cell Biol 7:612-618

Pathak R, Delorme-Walker VD, Howell MC, Anselmo AN, White MA, Bokoch GM, Dermardirossian C (2012) The microtubuleassociated Rho activating factor GEF-H1 interacts with exocyst complex to regulate vesicle traffic. Dev Cell 23:397-411

Pelletier L, Stern CA, Pypaert M, Sheff D, Ngo HM, Roper N, He CY, Hu K, Toomre D, Coppens I, Roos DS, Joiner KA, Warren G (2002) Golgi biogenesis in Toxoplasma gondii. Nature 418:548-552

Percival JM, Hughes JA, Brown DL, Schevzov G, Heimann K, Vrhovski B, Bryce N, Stow JL, Gunning PW (2004) Targeting of a tropomyosin isoform to short microfilaments associated with the Golgi complex. Mol Biol Cell 15:268-280

Peremyslov VV, Prokhnevsky AI, Dolja VV (2010) Class XI myosins are required for development, cell expansion, and F-Actin organization in Arabidopsis. Plant Cell 22:1883-1897

Picton JM, Steer MW (1981) Determination of secretory vesicle production rates by dictyosomes in pollen tubes of Tradescantia using cytochalasin D. J Cell Sci 49:261-272

Praefcke GJ, McMahon HT (2004) The dynamin superfamily: universal membrane tubulation and fission molecules? Nat Rev Mol Cell Biol 5:133-147

Preuss D, Mulholland J, Franzusoff A, Segev N, Botstein D (1992) Characterization of the Saccharomyces Golgi complex through the cell cycle by immunoelectron microscopy. Mol Biol Cell 3:789-803

Prigozhina NL, Waterman-Storer CM (2004) Protein kinase D-mediated anterograde membrane trafficking is required for fibroblast motility. Curr Biol 14:88-98

Pruyne D, Legesse-Miller A, Gao L, Dong Y, Bretscher A (2004) Mechanisms of polarized growth and organelle segregation in yeast. Annu Rev Cell Dev Biol 20:559-591

Ramabhadran V, Korobova F, Rahme GJ, Higgs HN (2011) Splice variant-specific cellular function of the formin INF2 in maintenance of Golgi architecture. Mol Biol Cell 22:4822-4833

Rambourg A, Clermont Y (1986) Tridimensional structure of the Golgi apparatus in type A ganglion cells of the rat. Am J Anat 176:393-409

Rambourg A, Jackson CL, Clermont Y (2001) Three dimensional configuration of the secretory pathway and segregation of secretion granules in the yeast Saccharomyces cerevisiae. J Cell Sci 114:2231-2239

Ramírez IB, Lowe M (2009) Golgins and GRASPs: holding the Golgi together. Semin Cell Dev Biol 20:770-779

Rappleye CA, Paredez AR, Smith CW, McDonald KL, Aroian RV (1999) The coronin-like protein POD-1 is required for anteriorposterior axis formation and cellular architecture in the nematode caenorhabditis elegans. Genes Dev 13:2838-2851

Rehberg M, Kleylein-Sohn J, Faix J, Ho TH, Schulz I, Graf R (2005) Dictyostelium LIS1 is a centrosomal protein required for microtubule/cell cortex interactions, nucleus/centrosome linkage, and actin dynamics. Mol Biol Cell 16:2759-2771

Ridley AJ (2006) Rho GTPases and actin dynamics in membrane protrusions and vesicle trafficking. Trends Cell Biol 16:522-529

Rios RM, Bornens M (2003) The Golgi apparatus at the cell centre. Curr Cell Biol 15:60-66

Rodriguez-Boulan E, Kreitzer G, Musch A (2005) Organization of vesicular trafficking in epithelia. Nat Rev Mol Cell Biol 6:233-247

Rossanese OW, Soderholm J, Bevis BJ, Sears IB, O'Connor J, Williamson EK, Glick BS (1999) Golgi structure correlates with transitional endoplasmic reticulum organization in Pichia pastoris and Saccharomyces cerevisiae. J Cell Biol 145:69-81

Rossanese OW, Reinke CA, Bevis BJ, Hammond AT, Sears IB, O'Connor J, Glick BS (2001) A role for actin, Cdc1p, and Myo2p in the inheritance of late Golgi elements in Saccharomyces cerevisiae. J Cell Biol 153:47-62

Rosso S, Bollati F, Bisbal M, Peretti D, Sumi T, Nakamura T, Quiroga S, Ferreira A, Caceres A (2004) LIMK1 regulates Golgi dynamics, traffic of Golgi-derived vesicles, and process extension in primary cultured neurons. Mol Biol Cell 15:3433-3449

Rozelle AL, Machesky LM, Yamamoto M, Driessens MH, Insall RH, Roth MG, Luby-Phelps K, Marriott G, Hall A, Yin HL (2000) Phosphatidylinositol 4,5-bisphosphate induces actin-based movement of raft-enriched vesicles through WASP-Arp2/3. Curr Biol 10:311-320

Rybakin V, Clemen CS (2005) Coronin proteins as multifunctional regulators of the cytoskeleton and membrane trafficking. Bioessays 27:625-632

Rybakin V, Stumpf M, Schulze A, Majoul IV, Noegel AA, Hasse A (2004) Coronin 7, the mammalian POD-1 homologue, localizes to the Golgi apparatus. FEBS Lett 573:161-167

Sahlender DA, Roberts RC, Arden SD, Spudich G, Taylor MJ, Luzio JP, Kendrick-Jones J, Buss F (2005) Optineurin links myosin VI to the Golgi complex and is involved in Golgi organization and exocytosis. J Cell Biol 169:285-295

Saint-Jore CM, Evins J, Batoko H, Brandizzi F, Moore I, Hawes C (2002) Redistribution of membrane proteins between the Golgi apparatus and endoplasmic reticulum in plants is reversible and not dependent on cytoskeletal networks. Plant J 29:661-678

Salcedo-Sicilia L, Granell S, Jovic M, Sicart A, Mato E, Johannes L, Balla T, Egea G (2013) BIII spectrin regulates the structural integrity and the secretory protein transport of the Golgi complex. J Biol Chem 288:2157-2166

Salvarezza SB, Deborde S, Schreiner R, Campagne F, Kessels MM, Qualmann B, Caceres A, Kreitzer G, Rodriguez-Boulan E (2009) LIM kinase 1 and cofilin regulate actin filament population required for dynamin-dependent apical carrier fission from the trans-Golgi network. Mol Biol Cell 20:438-451

Samaj J, Muller J, Beck M, Bohm N, Menzel D (2006) Vesicular trafficking, cytoskeleton and signalling in root hairs and pollen tubes. Trends Plant Sci 11:594-600

Santiago-Tirado FH, Legesse-Miller A, Schott D, Bretscher A (2011) PI4P and Rab inputs collaborate in myosin-V-dependent transport of secretory compartments in yeast. Dev Cell 20:47-59
1158

1159

1160

1161

1162

1163

1164

1165

1166

1167

1168

1169

1170

1171

1172

1173

1174

1175

1176

1177

1178

1179

1180

1181

1182

1183

1184

1185

1186

1187

1188

1189

1190

1191

1192

1193

1194

1195

1196

1197

1198

1199

1200

1201

1202

1203

1204

1205

1206

1207

1208

1209

1210

1211

1212

1213

1214

1215

1216

1217

1218

1219

1220

1221

1222 
Satiat-Jeunemaitre B, Cole L, Bourett T, Howard R, Hawes C (1996) Brefeldin A effects in plant and fungal cells: something new about vesicle trafficking? J Microsc 181:162-177

Shimmen T, Yokota E (2004) Cytoplasmic streaming in plants. Curr Opin Cell Biol 16:68-72

Siddhanta A, Radulescu A, Stankewich MC, Morrow JS, Shields D (2003) Fragmentation of the Golgi apparatus. A role for beta III spectrin and synthesis of phosphatidylinositol 4,5-bisphosphate. J Biol Chem 278:1957-1965

Sisson JC, Field C, Ventura R, Royou A, Sullivan W (2000) Lava lamp, a novel peripheral Golgi protein, is required for Drosophila melanogaster cellularization. J Cell Biol 151:905-918

Smythe E, Ayscough KR (2006) Actin regulation in endocytosis. J Cell Sci 119:4589-4598

Soldati T, Schliwa M (2006) Powering membrane traffic in endocytosis and recycling. Nat Rev Mol Cell Biol 7:897-908

Somesh BP, Neffgen C, Iijima M, Devreotes P, Rivero F (2006) Dictyostelium $\mathrm{RacH}$ regulates endocytic vesicular trafficking and is required for localization of vacuolin. Traffic 7:1194-1212

Sparkes I (2011) Recent advances in understanding plant myosin function: life in the fast lane. Mol Plant 4(5):805-812

Spelbrink RG, Nothwehr SF (1999) The yeast GRD20 gene is required for protein sorting in the trans-Golgi network/endosomal system and for polarization of the actin cytoskeleton. Mol Biol Cell 10:4263-4281

Stankewich MC, Tse WT, Peters LL, Ch'ng Y, John KM, Stabach PR, Devarajan P, Morrow JS, Lux SE (1998) A widely expressed betaIII spectrin associated with Golgi and cytoplasmic vesicles. Proc Natl Acad Sci USA 95:14158-14163

Storrie B, Micaroni M, Morgan GP, Jones N, Kamykowski JA, Wilkins N, Pan TH, Marsh BJ (2012) Electron tomography reveals Rab6 is essential to the trafficking of trans-Golgi clathrin and COPI-coated vesicles and the maintenance of Golgi cisternal number. Traffic 13:727-744

Stow JL, Fath KR, Burgess DR (1998) Budding roles for myosin II on the Golgi. Trends Cell Biol 8:138-141

Styers ML, Kowalczyk AP, Faundez V (2006) Architecture of the vimentin cytoskeleton is modified by perturbation of the GTPase ARF1. J Cell Sci 119:3643-3654

Sweeney HL, Houdusse A (2010) Myosin VI rewrites the rules for myosin motors. Cell 141:573-582

Taylor MJ, Lampe M, Merrifield CJ (2012) A feedback loop between dynamin and actin recruitment during clathrin-mediated endocytosis. PLoS Biol 10:e1001302

Thyberg J, Moskalewski S (1999) Role of microtubules in the organization of the Golgi complex. Exp Cell Res 246:263-279

Toivola DM, Tao GZ, Habtezion A, Liao J, Omary MB (2005) Cellular integrity plus: organelle-related and protein-targeting functions of intermediate filaments. Trends Cell Biol 15:608-617

Tyska MJ, Mackey AT, Huang JD, Copeland NG, Jenkins NA, Mooseker MS (2005) Myosin-1a is critical for normal brush border structure and composition. Mol Biol Cell 16:2443-2457
Uemura T, Yoshimura SH, Takeyasu K, Sato MH (2002) Vacuolar membrane dynamics revealed by GFP-AtVam3 fusion protein. Genes Cells 7:743-753

Valderrama F, Babia T, Ayala I, Kok JW, Renau-Piqueras J, Egea G (1998) Actin microfilaments are essential for the cytological positioning and morphology of the Golgi complex. Eur J Cell Biol 76:9-17

Valderrama F, Luna A, Babia T, Martinez-Menarguez JA, Ballesta J, Barth H, Chaponnier C, Renau-Piqueras J, Egea G (2000) The Golgi-associated COPI-coated buds and vesicles contain b/gactin. Proc Natl Acad Sci USA 97:1560-1565

Valderrama F, Duran JM, Babia T, Barth H, Renau-Piqueras J, Egea G (2001) Actin microfilaments facilitate the retrograde transport from the Golgi complex to the endoplasmic reticulum in mammalian cells. Traffic 2:717-726

Vidali L, McKenna ST, Hepler PK (2001) Actin polymerization is essential for pollen tube growth. Mol Biol Cell 12:2534-2545

von Blume J, Duran JM, Forlanelli E, Alleaume AM, Egorov M, Polishchuk R, Molina H, Malhotra V (2009) Actin remodeling by $\mathrm{ADF} /$ cofilin is required for cargo sorting at the trans-Golgi network. J Cell Biol 187:1055-1069

von Blume J, Alleaume AM, Cantero-Recasens G, Curwin A, Carreras-Sureda A, Zimmermann T, van Galen J, Wakana Y, Valverde MA, Malhotra V (2011) ADF/cofilin regulates secretory cargo sorting at the TGN via the $\mathrm{Ca}^{2+}$ ATPase SPCA1. Dev Cell 20:652-662

Wakana Y, van Galen J, Meissner F, Scarpa M, Polishchuk RS, Mann M, Malhotra V (2012) A new class of carriers that transport selective cargo from the trans Golgi network to the cell surface. EMBO J 31:3976-3990

Warner CL, Stewart A, Luzio JP, Steel KP, Libby RT, KendrickJones J, Buss F (2003) Loss of myosin VI reduces secretion and the size of the Golgi in fibroblasts from Snell's waltzer mice. EMBO J 22:569-579

Weiner OH, Murphy J, Griffiths G, Schleicher M, Noegel AA (1993) The actin-binding protein comitin (p24) is a component of the Golgi apparatus. J Cell Biol 123:23-34

Wu WJ, Erickson JW, Lin R, Cerione RA (2000) The $\gamma$-subunit of the coatomer complex binds $\mathrm{Cdc} 42$ to mediate transformation. Nature 405(6788):800-804

Yamaguchi M, Kopecka M (2010) Ultrastructural disorder of the secretory pathway in temperature-sensitive actin mutants of Saccharomyces cerevisiae. J Electron Microsc 59:141-152

Yang YD, Elamawi R, Bubeck J, Pepperkok R, Ritzenthaler C, Robinson DG (2005) Dynamics of COPII vesicles and the Golgi apparatus in cultured Nicotiana tabacum BY-2 cells provides evidence for transient association of Golgi stacks with endoplasmic reticulum exit sites. Plant Cell 17:1513-1531

Zilberman Y, Alieva NO, Miserey-Lenkei S, Lichtenstein A, Kam Z, Sabanay H, Bershadsky A (2011) Involvement of the RhomDial pathway in the regulation of Golgi complex architecture and dynamics. Mol Biol Cell 22:2900-2911

\begin{tabular}{|l|lll|}
\hline & Journal : Large 418 & Dispatch : 24-6-2013 & Pages : $\mathbf{1 4}$ \\
Article No. : $\mathbf{1 1 1 5}$ & $\square_{\mathrm{CP}}^{\mathrm{LE}}$ & $\checkmark_{\mathrm{TISK}}^{\mathrm{TYPESET}}$ \\
\hline
\end{tabular}

